\title{
The $\mathbf{A}_{3}$ Adenosine Receptor Induces Cytoskeleton Rearrangement in Human Astrocytoma Cells via a Specific Action on Rho Proteins
}

\author{
MARIA P. ABBRACCHIO ${ }^{\mathrm{a}}$, ALESSANDRA CAMURRI ${ }^{\mathrm{a}}$, STEFANIA CERUTI ${ }^{\mathrm{a}}$, FLAMINIO

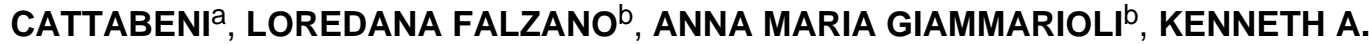 \\ JACOBSON $^{\mathrm{c}}$, LETIZIA TRINCAVELLI ${ }^{\mathrm{d}}$, CLAUDIA MARTINI ${ }^{\mathrm{d}}$, WALTER MALORNI ${ }^{\mathrm{b}}$, and \\ CARLA FIORENTINI ${ }^{\mathrm{b}}$ \\ aDepartment of Pharmacological Sciences, University of Milan, Milan, Italy \\ blstituto Superiore di Sanità, Rome, Italy \\ cMolecular Recognition Section, Laboratory of Bioorganic Chemistry, National Institute of \\ Diabetes, Digestive and Kidney Diseases, National Institutes of Health, Bethesda, Maryland, \\ U.S.A.
}

dDepartment of Psychiatry, Neurobiology, Pharmacology and Biotechnology, University of Pisa, Pisa, Italy

\section{Abstract}

In previous studies, we have demonstrated that exposure of astroglial cells to $\mathrm{A}_{3}$ adenosine receptor agonists results in dual actions on cell survival, with "trophic" and antiapoptotic effects at nanomolar concentrations and induction of cell death at micromolar agonist concentrations. The protective actions of $\mathrm{A}_{3}$ agonists have been associated with a reinforcement of the actin cytoskeleton, which likely results in increased resistance of cells to cytotoxic stimuli. The molecular mechanisms at the basis of this effect and the signalling pathway(s) linking the $\mathrm{A}_{3}$ receptor to the actin cytoskeleton have never been elucidated. Based on previous literature data suggesting that the actin cytoskeleton is controlled by small GTP-binding proteins of the Rho family, in the study reported here we investigated the involvement of these proteins in the effects induced by $\mathrm{A}_{3}$ agonists on human astrocytoma ADF cells. The presence of the $\mathrm{A}_{3}$ adenosine receptor in these cells has been confirmed by immunoblotting analysis. As expected, exposure of human astrocytoma $\mathrm{ADF}$ cells to nanomolar concentrations of the selective $\mathrm{A}_{3}$ agonist 2-chloro$\mathrm{N}^{6}$-(3-iodobenzyl)-adenosine-5'- $\mathrm{N}$-methyluronamide (Cl-IB-MECA) resulted in formation of thick actin positive stress fibers. Preexposure of cells to the $\mathrm{C} 3 \mathrm{~B}$ toxin that inactivates Rho-proteins completely prevented the actin changes induced by Cl-IB-MECA. Exposure to the $\mathrm{A}_{3}$ agonist also resulted in significant reduction of Rho-GDI, an inhibitory protein known to maintain Rho proteins in their inactive state, suggesting a potentiation of Rho-mediated effects. This effect was fully counteracted by the concomitant exposure to the selective $A_{3}$ receptor antagonist MRS1191. These results suggest that the reinforcement of the actin cytoskeleton induced by $\mathrm{A}_{3}$ receptor

Address for correspondence: Professor Maria P. Abbracchio, Department of Pharmacological Sciences, University of Milan, Via Balzaretti 9, 20133 Milan, Italy. Voice: +39-02-20488310; fax: +39-02-29404961. Mariapia.Abbracchio@unimi.it. 
agonists is mediated by an interference with the activation/inactivation cycle of Rho proteins, which may, therefore, represent a biological target for the identification of novel neuroprotective strategies.

\section{Keywords}

Adenosine; $\mathrm{A}_{3}$ receptor; Neuroprotection; Rho proteins

\section{INTRODUCTION}

The actions of adenosine are mediated by four G-protein coupled membrane receptors, the $A_{1}, A_{2 A}, A_{2 B}$, and $A_{3}$ receptors. ${ }^{1}$ Although the existence of the $A_{1}, A_{2 A}$, and $A_{2 B}$ receptors was postulated before they were cloned, the $\mathrm{A}_{3}$ receptor was discovered by cloning, initially from rat and subsequently from human tissues. ${ }^{2}$ The development of selective agonists, such as $\mathrm{N}^{6}$-(3-iodobenzyl)-adenosine-5'- $N$-methyluronamide (IB-MECA) ${ }^{3}$ and its 2-chloroderivative (Cl-IB-MECA), ${ }^{4}$ and more recently, antagonists, such as MRS1191 (3-ethyl-5benzyl-2-methyl-6-phenyl-4-phenylethynyl-1,4-( \pm )-dihydropyridine-3,5-dicarboxyla-te), ${ }^{5}$ and MRS1220 (9-chloro-2-(2-furyl)-5-phenyl-acetylamino-[1,2,4]-triazolo-[1,5-c]quinazoline $)^{6}$ has played a crucial role in defining the putative pathophysiological roles of this receptor.

The $\mathrm{A}_{3}$ receptor is involved in inflammation, ${ }^{2}$ hypotension and mast cell degranulation, ${ }^{7}$ ischemic heart preconditioning. ${ }^{2}$ Although expressed to quite low levels in the brain, ${ }^{8}$ this receptor has also been implicated in behavioral depression ${ }^{8}$ and modulation of cerebral ischemic damage. ${ }^{9}$ Use of selective $\mathrm{A}_{3}$ agonists also revealed that this receptor profoundly affects cell survival, by promoting both cell protection and cell death, depending upon the cell type and/or the agonist concentrations. At low concentrations in the nanomolar range, $\mathrm{A}_{3}$ agonists reduce hypoxic heart damage ${ }^{10}$ and protect HL-60, U-937 cells, and mammalian astrocytes from apoptosis. ${ }^{11,12}$ In astroglial cells, increased resistance to apoptosis was associated with a reinforcement of the actin cytoskeleton and with the intracellular redistribution of the antiapoptotic protein $\mathrm{Bcl}-\mathrm{x}_{\mathrm{L}} \cdot{ }^{12,13}$ At high concentrations in the micromolar range, these same agonists markedly impaired cell cycle progression ${ }^{14}$ and induced death of cerebellar granule neurons, ${ }^{15} \mathrm{HL}-60$ cells, ${ }^{16}$ human lymphocytes, ${ }^{17}$ and astroglial cells. ${ }^{12}$ These dual actions confirm the concept that adenosine may represent a signal of both life and death for its target cells, simply depending on specific pathophysiological conditions. ${ }^{18}$

A hypothesis that may reconcile the opposite effects of adenosine on brain cell survival and give them a pathophysiological significance has recently been raised. ${ }^{19}$ In traumatic and ischemic brain, large amounts of adenosine are released from nucleic acids of dying cells as a result of increased neurotransmitter release and break-down of nucleotides and nucleosides. ${ }^{20}$ Hence, concentrations of adenosine in the ischemic brain are believed to depend on the extent of cellular damage; that is, to attain their highest values within the ischemic "core" area and to gradually decrease progressively in the direction of the "penumbra" area. ${ }^{19}$ Hence, within the core itself, adenosine is likely to reach levels that 
fully activate the $A_{3}$ receptor, resulting in the full range of its destructive effects to favour the elimination of irreversibly damaged cells and to save space and energy for those cells that retain the ability to recover. ${ }^{19}$ In contrast, in the penumbral area, the progressively lower concentrations of adenosine would lead to a milder, "subthreshold", stimulation of the $\mathrm{A}_{3}$ receptor, to result in more benign actions, such as increased resistance of cells to stress, anti-apoptotic effects, and recovery of damaged neurons via a potentiation of the astrocytic support to these cells. ${ }^{19}$

The molecular mechanisms underlying the protective effects mediated by the $\mathrm{A}_{3}$ receptor remain obscure. As mentioned above, in human astrocytoma cells, the cytoskeletal rearrangement induced by nanomolar $\mathrm{A}_{3}$ agonist concentrations is characterized by a marked increase of F-actin stress fibers. ${ }^{12,13}$ Since actin polymerization is crucially controlled by small GTP binding proteins of the Rho family, ${ }^{21}$ in the study reported here we tested whether the cytoprotective effects induced by $\mathrm{A}_{3}$ agonists may be mediated by a specific action on this system.

Under basal, unstimulated conditions, Rho proteins are found in the cytoplasm, where they are maintained in their inactive GDP bound state by guanine nucleotide dissociation inhibitors (Rho-GDIs) ${ }^{21}$ (see FIGURE 1). Exchange of GDP with GTP results in release of RhoGDI, binding of Rho to a family of stimulatory proteins (Rho-GDS) and migration of the activated Rho protein to the membrane (FIG. 1). Here, activated Rho can interact with a variety of different targets, mainly kinases, that in turn activate a number of proteins, including those regulating the actin cytoskeleton, such as specific membrane associated proteins (e.g., ERM, Ezrin/Radixin/Moesin). ${ }^{22}$ As a result of such interactions, actin fibers organize to form filamentous structures, termed stress fibers. Return of Rho proteins to their inactive state is favored by proteins that promote the hydrolysis of GTP to GDP (RhoGAPs) and binding to Rho-GDI (FIg. 1). The activation/inactivation cycle of Rho proteins is crucially regulated by guanine nucleotide exchange factors (GEFs) that can in turn be activated by several signals merging on Rho proteins. Rho links membrane receptors, activated by extracellular factors such as lysophosphatidic acid (LPA), bombesin, or thrombin, to the formation of actin stress fibers and focal adhesion contacts, ${ }^{22}$ through various signalling pathways, including tyrosine kinases, cAMP and phospholipaseC/protein kinase. ${ }^{23}$ It is presently unknown whether activation of the $\mathrm{A}_{3}$ receptor can result in signalling to Rho proteins. However, this receptor has been previously shown to activate phospholipase C (PLC) in the brain. ${ }^{24}$

\section{MATERIALS AND METHODS}

\section{Cell Culture and Treatment}

Human astrocytoma ADF cells were grown at $37^{\circ} \mathrm{C}$ in humidified atmosphere as previously described. ${ }^{25}$ After $24 \mathrm{~h}$ in culture, cells were exposed to Cl-IB-MECA in the absence or presence of MRS 1191 for $48 \mathrm{~h}$ prior to analysis. In selected experiments, before addition of Cl-IB-MECA, cells were exposed to the chimeric toxin C3B $(0.5 \mathrm{microg} / \mathrm{ml})$ for three hour, and then the toxin was maintained in the medium for the remainder of the experiment (which lasted $48 \mathrm{~h}$ ). This toxin consists of the $\mathrm{C} 3$ isoenzyme linked to the binding portion of the diphtheria toxin, and has been shown to specifically ADP-ribosylate Rho, rendering it 
inactive (for more details on the effects of C3B, see Refs. 23 and 26) The $\mathrm{A}_{3}$ selective agonist Cl-IB-MECA and antagonist MRS1191 were synthesized as described elsewhere. ${ }^{4,5}$

\section{Analytical Cytology}

For actin staining, ADF cells were fixed with $3.7 \%$ formaldehyde in PBS (pH 7.4) for 20 min at room temperature. After washing in the same buffer, cells were permeabilized with 0.5\% Triton X-100 (Sigma) in PBS for five minute at room temperature. Cells were stained with fluorescein-phalloidin (Sigma) at $37^{\circ} \mathrm{C}$ for $30 \mathrm{~min}$. Finally, after washing, all the samples were mounted with glycerol-PBS (2: 1) and observed with a Nikon Microphot fluorescence microscope.

\section{Western Blot Analysis}

Detection of the $\mathbf{A}_{\mathbf{3}}$ Adenosine Receptor-Cells at subconfluency were washed, scraped and incubated in lysis buffer $\left(9.1 \mathrm{mM} \mathrm{Na}_{2} \mathrm{H}_{2} \mathrm{PO}_{4} ; 1.7 \mathrm{mM} \mathrm{Na}_{2} \mathrm{HPO}_{4} ; 150 \mathrm{mM}\right.$ $\mathrm{NaCl}, \mathrm{pH} 7.4 ; 0.5 \%$ sodium deoxycholate; $1 \%$ Nonidet P-40; $0.1 \%$ SDS, containing proteinase inhibitors) for $60 \mathrm{~min}$ at $4^{\circ} \mathrm{C}$. After centrifugation, proteins were assayed in the soluble fraction and lysates $(1 \mathrm{mg})$ incubated overnight at $4{ }^{\circ} \mathrm{C}$ with an antibody raised against the human $\mathrm{A}_{3}$ receptor (Alfa-Diagnostic, San Antonio, TX, U.S.A.; $4 \mu \mathrm{g} / \mathrm{ml}$ ). The immunocomplex was precipitated with Protein-A sepharose $(50 \mu \mathrm{g})$ for two hours at $4^{\circ} \mathrm{C}$. The beads were washed with buffer $(150 \mathrm{mM} \mathrm{NaCl}, 10 \mathrm{mM}$ Tris, $1 \%$ NP-40) three times, and bound proteins solubilized in Laemmli buffer. For immunoblotting, equivalent amounts of protein (typically $100 \mu \mathrm{g} / \mathrm{samples}$ ) were resolved on $12 \%$ (w/v) sodiumdodecylsulphate (SDS) polyacrilamide gels. Resolved proteins were transferred to nitrocellulose and incubated with the primary anti- $\mathrm{A}_{3}$ receptor antibody $\left(1 \mu \mathrm{g} / \mathrm{ml}\right.$ overnight at $\left.4{ }^{\circ} \mathrm{C}\right)$. After extensive washing with TBS (10 mM Tris-HCL, $150 \mathrm{mM} \mathrm{NaCl}, \mathrm{pH}$ 8) containing $0.05 \%$ Tween-20, the nitrocellulose membrane was incubated for $120 \mathrm{~min}$ at room temperature with horseradish peroxidase (HRP) goat anti-rabbit conjugated secondary antibody diluted to $1: 2,000$ in Blotto. After several washes, reactive proteins were visualized by an enhanced chemiluminescence protocol ECL (Amersham Pharmacia Biotech). Immunoblotting was quantified by densitometric scanning of films exposed in the linear range. For these experiments, $\mathrm{CHO}$ cells transfected with the human $\mathrm{A}_{3}$ adenosine receptor cDNA were used as a positive control. ${ }^{14}$

Detection of Rho-GDI-Samples, containing about $20 \mu \mathrm{g}$ protein each, were then loaded on $11 \%$ sodiumdodecylsulphate (SDS) polyacrilamide gels and blotted onto nitrocellulose filters. Filters were then incubated with rabbit polyclonal antibody anti-Rho-GDI (1:4,000, Santa Cruz Biotechnology), followed by a secondary antirabbit antibody (peroxidase conjugated, 1:4000), and reactive proteins visualized and quantified as described above. In selected experiments, changes of Rho-GDI were also confirmed by immunoprecipitation. In this case, samples, containing about $30 \mu \mathrm{g}$ protein, prepared as described above, were incubated with anti-Rho-GDI polyclonal antibody overnight at $4{ }^{\circ} \mathrm{C}(1 \mu \mathrm{g} / \mathrm{sample})$. Rho-GDI immunoprecipitates were then incubated with protein-A-agarose (Santa Cruz Biotechnology, one hour, room temperature) and the immune complexes were centrifuged. The supernatants were then collected and added of sample buffer ( $187.5 \mathrm{mM}$ Tris-HCl, 6\% SDS, 30\% glycerol, 15\% B-mercaptoethanol, 0.003\% bromophenol blue), whereas the precipitates 
were washed with PBS and resuspended in water and sample buffer. Samples from both supernatants and precipitates were loaded on $11 \%$ sodium-dodecylsulphate polyacrylamide gels and processed as described above.

\section{RESULTS}

The presence of the $\mathrm{A}_{3}$ adenosine receptor in human astrocytoma ADF cells has been confirmed by inmmunoblotting analysis with a specific antibody raised against the human $\mathrm{A}_{3}$ receptor, and by using $\mathrm{CHO}$ cells expressing this receptor subtype to high levels as a positive control. ${ }^{14}$ In both $\mathrm{CHO}$ and $\mathrm{ADF}$ cells, a specific immunoreactive protein band with an apparent molecular weight of $36 \mathrm{kDa}$ corresponding to that of the $\mathrm{A}_{3}$ receptor $^{1}$ could be detected (see FIGURE 2).

As expected, exposure of ADF cells to the $\mathrm{A}_{3}$ receptor agonist Cl-IB-MECA (100 nM for 48 h) resulted in marked cytoskeletal rearrangement, as demonstrated by the appearance of thick F-actin positive stress fibers (compare FIGURE $3 \mathrm{~b}$ with control, FIGURE 3 a). Inhibition of Rho, as a result of exposure of cells to the $\mathrm{C} 3 \mathrm{~B}$ toxin, provoked retraction of the cell body and breakdown of the actin cytoskeleton ( $\mathrm{F}_{\mathrm{IG}} .3 \mathrm{c}$ ). This effect is not associated with a permanent disruption of the actin cytoskeleton, since C3B toxin-treated cells still respond to agents (e.g., cytotoxic necrotizing factor- $1^{27}$ ) that stimulate actin polymerization. Hence, $\mathrm{C} 3 \mathrm{~B}$ toxin is widely used to assess the involvement of Rho in cellular function. ${ }^{23}$ Addition of Cl-IB-MECA to C3B toxin treated astrocytoma cells could not reproduce the typical actin changes normally induced by the $\mathrm{A}_{3}$ agonist (compare FIGS. $3 \mathrm{~d}$ and $3 \mathrm{~b}$ ), suggesting that integrity of Rho is needed to mediate such effects. To evaluate whether Cl-IB-MECA can affect the expression of Rho-GDI, we performed Western blot analysis with a specific antiRho-GDI antibody. As expected, ${ }^{28}$ Rho-GDI was detected as a specific protein band with a molecular weight of $28 \mathrm{kDa}$ (see Figure $4 \mathrm{~A}$ ). A 48-h exposure of cells to $100 \mathrm{nM} \mathrm{Cl-IB-}$ MECA resulted in a marked reduction of this protein band with respect to control cells ( $F_{\text {IG. }}$. 4 A). A specific role for the $A_{3}$ receptor in this effect was demonstrated by the ability of the selective $\mathrm{A}_{3}$ antagonist MRS1191 to fully prevent Cl-IB-MECA-induced reduction of the 28-kDa protein band (FIG. 4 A).

These data have also been confirmed by an immunoprecipation technique. Cell homogenates have been incubated with the anti-Rho-GDI antibody, and the immunocomplex quantified in precipitates. The results indicated in FIGURE 3 B show that, under the experimental conditions used (see M M aterials and Methods), immunoprecipation was complete, with no detectable residual immunoreactivity for Rho-GDI in the supernatants of both control and treated cells. A notable reduction of the amount of Rho-GDI was also detected with this methodology after exposure of cells to Cl-IB-MECA (FIG. 4 B), hence confirming the results described in FIGURE 4 A.

\section{DISCUSSION}

The adenosine $\mathrm{A}_{3}$ receptor has been reported to be expressed at low levels in brain-derived tissues. ${ }^{1,8}$ For this reason, we deemed it important to confirm its presence in the human astrocytoma cells used in this study. Immunoblotting analysis performed with a specific 
antibody raised against the human $\mathrm{A}_{3}$ receptor confirmed that these cells do indeed express the receptor protein to significant levels, hence validating this experimental model for studying the functional effects mediated by this receptor in cells of the astroglial lineage. The present data also demonstrate for the first time that activation of the adenosine $\mathrm{A}_{3}$ receptor results in signaling to the small G-protein Rho, possibly through the phospholipase C pathway. ${ }^{24}$ Moreover, they suggest that the previously reported reinforcement of the actin cytoskeleton on exposure to selective $\mathrm{A}_{3}$ agonists ${ }^{12,13}$ is mediated by an interference with the activation/inactivation cycle of Rho-proteins. This conclusion is based on the following evidence: (1) inhibition of Rho with the specific C3B toxin completely abolishes the actin changes induced by the $\mathrm{A}_{3}$ selective agonist Cl-IB-MECA; and (2) exposure of cells to $\mathrm{Cl}$ IB-MECA under experimental conditions that are associated with cell protection (i.e., 100 $\mathrm{nM}$ for $48 \mathrm{~h}$ ) resulted in a reduction of Rho-GDI, as demonstrated by both standard Western blot analysis and by immunoprecipitation. We do not know at present whether the detected reduction of Rho-GDI is a result of diminished protein synthesis, of increased protein turn over, and/or induction of conformational changes that decrease its ability to bind to both Rho (FIg. 1) and to the anti-Rho-GDI antibody. Experiments specifically aimed at quantifying the expression of Rho-GDI (i.e., reverse transcriptase polymerase chain reaction) will enable us to shed light on the mechanisms underlying this effect. However, this result indirectly suggests a potentiation of Rho mediated effects. A lower availability of the inhibitory protein necessary to keep Rho at a basal, unstimulated state may in fact result in a higher percentage of GDS bound Rho, which in turn would lead to increased Rho activation and stimulation of actin polymerization (FIG. 1). To confirm this hypothesis, we plan to used the immunoprecipitation technique to quantify GDI-bound Rho proteins in immunoprecipitates after incubation of cell homogenates with the anti-Rho-GDI antibody. If stimulation of the $\mathrm{A}_{3}$ receptor increases the percentage of Rho activation, smaller amounts of Rho proteins are expected to coimmunoprecipate with Rho-GDI in $\mathrm{A}_{3}$ agonist-treated cells. We also plan to identify the Rho protein(s) involved in this effect by using antibodies that specifically recognize the various members of this family (i.e., Rho-A, Rho-B, Rho-C, $\mathrm{rac} 1 / 2$, cdc42, etc). ${ }^{21}$ Of course, we cannot rule out the possibility that activation of the $\mathrm{A}_{3}$ receptor leads to a direct stimulation of GEFs, which would directly potentiate Rho (FIG. 1). In this case, the detected reduction of Rho-GDI represents a compensatory mechanism aimed at counteracting the excessive activation of the system.

Our data also imply that Rho activation via a subthreshold stimulation of the $\mathrm{A}_{3}$ receptor (as that attained by nanomolar agonist concentrations) is associated with cell protection; that is, inhibition of apoptosis. ${ }^{12}$ It is not clear at present whether induction of cell death upon a robust activation of this receptor (as that attained with micromolar agonist concentrations) also occurs through modulation of Rho proteins. By using other experimental paradigms, ${ }^{29}$ it has been demonstrated that prolonged inhibition of Rho is indeed associated with induction of apoptosis. It has been hypothesized that the dual effects induced by the $\mathrm{A}_{3}$ receptor may depend on either the state of receptor activation and/or induction of receptor desensitization by high agonist concentrations. ${ }^{19,20}$ We suggest that, depending upon the agonist concentrations, the degree of receptor activation may regulate the balance between Rho activation/inactivation, which in turn regulates the susceptibility to cell death. 
The elucidation of the molecular mechanisms forming the basis of the protective effects induced by $\mathrm{A}_{3}$ agonists may have important pathophysiological implications. Besides their established role in cardioprotection ${ }^{30}$ and their putative contribution to neuronal recovery in brain ischemic penumbra, ${ }^{19,20}$ these effects may also play a role in the development of brain preconditioning, a phenomenon according to which a brief ischemic attack can protect the brain from a subsequent, and lethal, stronger ischemic insult. ${ }^{31}$ The demonstration that such protection is mediated by modulation of Rho proteins activity may disclose further biological targets for the identification of novel antiischemic and neuroprotective strategies.

\section{ACKNOWLEDGMENTS}

This work was supported by the Italian National Research Council (CNR) Contributo di Ricerca No. 98.01047.CT04 to MPA and by the Ministero dell'Universita' e della Ricerca Scientifica e Tecnologica (MURST), Cofinanziamento di ricerche di interesse nazionale 1999 to FC on "Recettori purinergici e neuroprotezione". The authors are grateful to Dr. Charly Klotz (University of Wurzburg, Germany) for kindly providing CHO cells tranfected with the human $\mathrm{A} 3$ adenosine receptor.

\section{REFERENCES}

1. FREDHOLM BB, ABBRACCHIO MP, BURNSTOCK G, et al. Nomenclature and classification of purinoceptors. Pharm. Rev. 1994; 46:143-156. [PubMed: 7938164]

2. LINDEN J. Cloned adenosine $A_{3}$ receptors: pharmacological properties, species-differences and receptor functions. Trends Pharmacol. Sci. 1994; 15:298-306. [PubMed: 7940998]

3. GALLO-RODRIGUEZ C, JI X-D, MELMAN N, et al. Structure-activity-relationships of N6. benzyladenosine-5'-uronamides as A3-selective adenosine agonists. J. Med. Chem. 1994; 37:636646. [PubMed: 8126704$]$

4. KIM HO, JI XD, SIDDIQI SM, et al. 2-Substitution of $\mathrm{N}^{6}$-benzyladenosine-5' -uronamides enhances selectivity for $\mathrm{A}_{3}$-adenosine receptors. J. Med. Chem. 1994; 37:3614-3621. [PubMed: 7932588]

5. JACOBSON KA, PARK KS, JIANG JI, et al. Pharmacological characterization of novel $\mathrm{A}_{3}$ adenosine receptor-selective antagonists. Neuropharmacol. 1997; 36:1157-1165.

6. KIM YC, JI XD, JACOBSON KA. Derivatives of the triazoloquinazoline adenosine antagonist (CGS15943) are selective for the human A 3 receptor subtype. J. Med. Chem. 1996; 39:4142-4148. [PubMed: 8863790]

7. HANNON JP, PFANNKUCHE HJ, FOZARD JR. A role for mast cells in adenosine $\mathrm{A}_{3}$ receptormediated hypotension in the rat. Br. J. Pharmacol. 1995; 115:945-952. [PubMed: 7582525]

8. JACOBSON KA, NIKODIJEVIC O, SHI D, et al. A role for central A 3 -adenosine receptors: mediation of behavioral depressant effects. FEBS Lett. 1993; 336:57-60. [PubMed: 8262217]

9. VON LUBITZ DKJE, LIN RCS, POPIK P, et al. Adenosine $A_{3}$ receptor stimulation and cerebral ischemia. Eur. J. Pharmacol. 1994; 263:59-67. [PubMed: 7821362]

10. STAMBAUGH C, JIANG JL, JACOBSON KA, LIANG BT. Novel cardioprotective function of adenosine $A_{3}$ receptor during prolonged simulated ischemia. Am. J. Physiol. 1997; 273:H501H505. [PubMed: 9249524]

11. YAO Y, SEI Y, ABBRACCHIO MP, et al. Adenosine $A_{3}$ receptor agonists protect HL-60 cells and U-937 cells from apoptosis induced by $\mathrm{A}_{3}$ antagonists. Biochem. Biophys. Res. Commun. 1997; 232:317-322. [PubMed: 9125172]

12. ABBRACCHIO MP, CERUTI S, BRAMBILLA R, et al. Adenosine $\mathrm{A}_{3}$ receptors and viability of astrocytes. Drug Dev. Res. 1998; 45:379-386.

13. ABBRACCHIO MP, RAINALDI G, GIAMMARIOLI AM, et al. The $\mathrm{A}_{3}$ adenosine receptor mediates cell spreading, reorganization of actin cytoskeleton, and distribution of Bcl- $\mathrm{x}_{\mathrm{L}}$. Studies in human astroglioma cells. Biochem. Biophys. Res. Commun. 1997; 241:297-304. [PubMed: 9425266]

14. BRAMBILLA R, CATTABENI F, CERUTI S, et al. Activation of the $A_{3}$ Adenosine Receptor Affects Cell Cycle Progression and Cell Growth. N-S Arch. Pharmacol. 2000; 361:224-234. 
15. SEI Y, VON LUBITZ DKJE, ABBRACCHIO MP, et al. Adenosine $\mathrm{A}_{3}$ receptor agonist-induced neurotoxicity in rat cerebellar granule neurons. Drug Dev. Res. 1997; 40:267-273.

16. KOHNO Y, SEI Y, KOSHIBA M, et al. Induction of apoptosis in HL-60 human promyelocytic leukemia cells by selective adenosine $\mathrm{A}_{3}$ receptor agonists. Biochem. Biophys. Res. Commun. 1996; 219:904-910. [PubMed: 8645277]

17. BARBIERI D, ABBRACCHIO MP, SALVIOLI S, et al. Apoptosis by 2-chloro-2'-deoxyadenosine and 2-chloro-adenosine in human peripheral blood mononuclear cells. Neurochem. Int. 1997; 32:493-504. [PubMed: 9676749]

18. JACOBSON KA, HOFFMANN C, CATTABENI F, ABBRACCHIO MP. Adenosine-induced cell death: evidence for receptor-mediated signalling. Apoptosis. 1999; 4:197-211. [PubMed: 14634282]

19. VON LUBITZ DKJE, YE W, MCCLELLAN J, LIN RCS. Stimulation of adenosine $\mathrm{A}_{3}$ receptors in cerebral ischemia. Neuronal death, recovery, or both? Ann. N.Y. Acad. Sci. 1999; 890:93-106. [PubMed: 10668416]

20. ABBRACCHIO MP, CATTABENI F. Brain adenosine receptors as targets for therapeutic intervention in neurodegenerative diseases. Ann. N.Y. Acad. Sci. 1999; 890:79-92. [PubMed: 10668415]

21. HALL A. Rho GTPases and the actin cytoskeleton. Science. 1998; 279:509-514. [PubMed: 9438836]

22. BISHOP AL, HALL A. Rho GTPases and their effector proteins. Biochem. J. 2000; 348:241-255. [PubMed: 10816416]

23. SEASHOLTZ TM, MAJUMDAR M, HELLER BROWN J. Rho as a mediator of G-proteincoupled receptor signaling. Mol. Pharmacol. 1999; 55:949-956. [PubMed: 10347235]

24. ABBRACCHIO MP, BRAMBILLA R, CERUTI S, et al. G-protein-dependent activation of phospholipase $\mathrm{C}$ by adenosine $\mathrm{A}_{3}$ receptors in rat brain. Mol. Pharmacol. 1995; 48:1038-1045. [PubMed: 8848003]

25. MALORNI W, RAINALDI G, RIVABENE R, SANTINI MT. Different susceptibilities to cell death induced by t-butylhydroperoxide could depend upon cell histotype-associated growth features. Cell Biol. Toxicol. 1994; 10:207-218. [PubMed: 7895150]

26. AULLO P, GIRY M, POPOFF MR, et al. A chimeric toxin to study the role of the $21 \mathrm{kDa}$ GTP binding protein rho in the control of actin microfilament assembly. EMBO J. 1993; 12:921-931. [PubMed: 8458345]

27. FIORENTINI C, FABBRI A, FLATAU G, et al. Escherichia coli cytotoxic necrotizing factor 1 (CNF1), a toxin that activates the rho GTPase. J. Biol. Chem. 1997; 272:19532-19537. [PubMed: 9235957]

28. HIRAO M, SATO N, KONDO T, et al. Regulation mechanism of ERM (Erzin/Radixin/Moesin) protein/plasma membrane association: possible involvement of phosphatidylinositol turnover and Rho-dependent signaling pathway. J. Cell Biol. 1996; 135:37-51. [PubMed: 8858161]

29. FIORENTINI C, FABBRI A, FALZANO L, et al. Clostridium difficile toxin B induces apoptosis in intestinal cultured cells. Infect. Immun. 1998; 66:2660-2665. [PubMed: 9596731]

30. LIANG BT, JACOBSON KA. A physiological role of the adenosine $\mathrm{A}_{3}$ receptor: sustained cardioprotection. Proc. Natl. Acad. Sci. U.S.A. 1998; 95:6995-6999. [PubMed: 9618527]

31. KITAGAWA K, MATSUMOTO M, TAGAYA M, et al. "Ischemic tolerance" phenomenon found in the brain. Brain Res. 1990; 528:21-24. [PubMed: 2245337] 


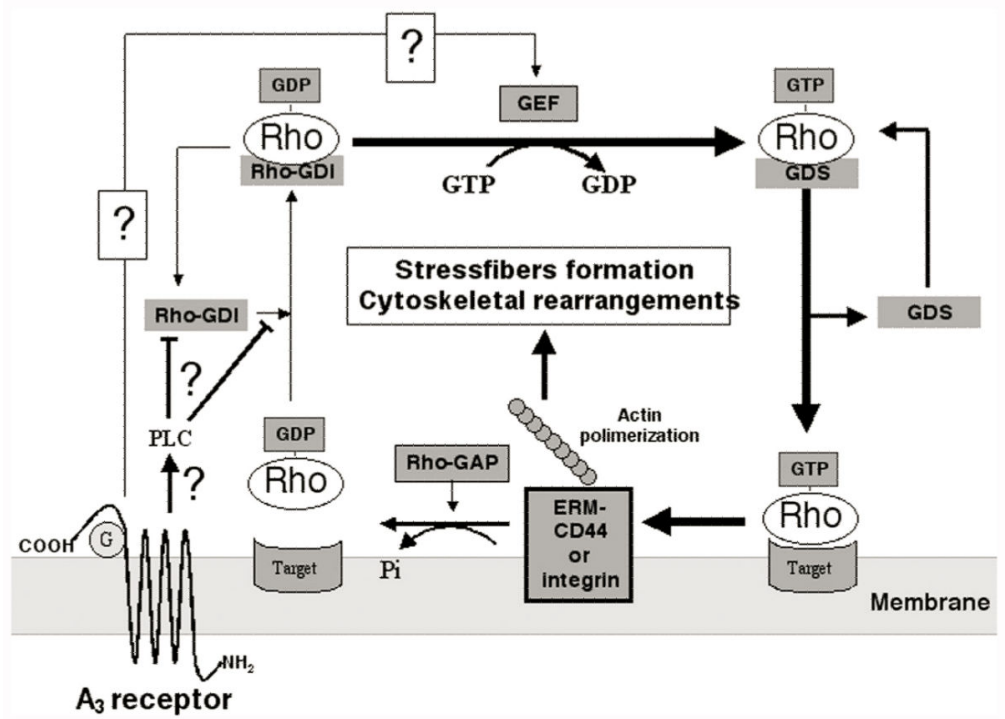

FIGURE 1.

Schematic representation of the putative relationship between the adenosine $\mathrm{A}_{3}$ receptor and Rho proteins. Under basal, unstimulated conditions, Rho proteins are maintained in their GDP bound inactive state by Rho-GDI. Stimulation of GDP exchange with GTP via guanine nucleotide exchange factors (GEF) results in release of Rho-GDI, binding of Rho to RhoGDS and migration of the activated Rho protein to the membrane. Here, Rho can interact with its targets (mainly kinases) that in turn activate a number of proteins, including integrins, CD44, and proteins involved in regulation of the actin cytoskeleton, such as ERM (Ezrin/Radixin/Moesin). Interaction with actin promotes its polymerization and the formation of F-actin stress fibers (as an example, see FIG. 3 b). Return of Rho protein to its inactive state is favoured by proteins that promote the hydrolysis of GTP to GDP (RhoGAPs) and binding to Rho-GDI. These results suggest that stimulation of the $\mathrm{A}_{3}$ receptor, likely through PLC, ${ }^{24}$ can influence the activation/inactivation cycle of Rho proteins. This could be achieved by either a direct stimulation of GEFs and/or by modulation of Rho-GDI. Data show that exposure to $\mathrm{A}_{3}$ agonists reduces Rho-GDI availability, by either reducing its expression or by promoting conformational changes that decrease its ability to bind to Rho. This would lead to a potentiation of Rho-mediated effects (thick arrows). See text for further details. 


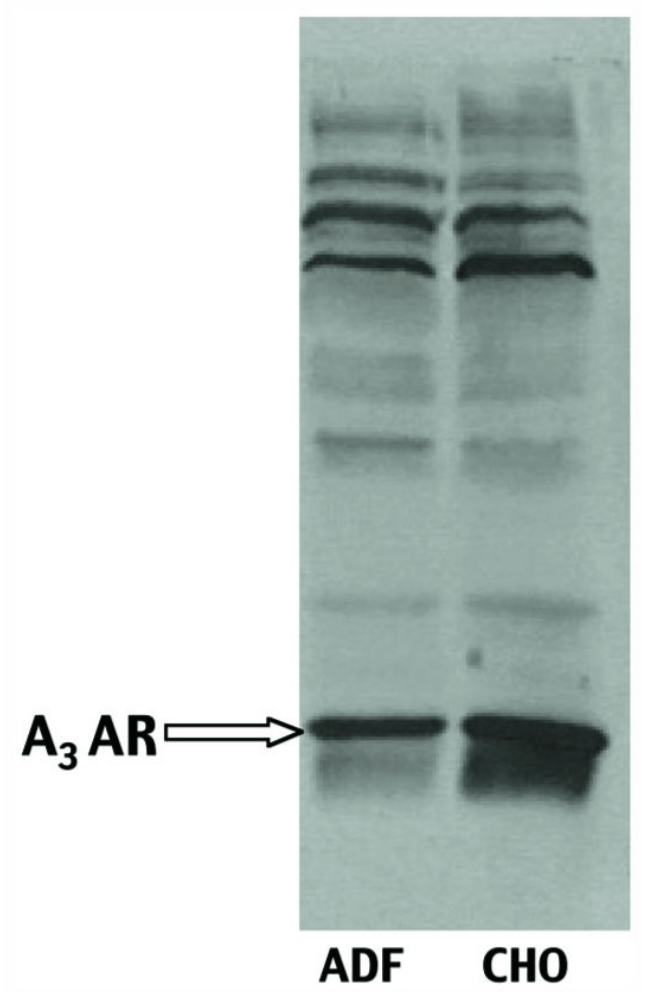

FIGURE 2.

Detection of the $\mathrm{A}_{3}$ adenosine receptor $\left(\mathrm{A}_{3} \mathrm{AR}\right)$ by immunoblotting analysis in human astrocytoma ADF cells. After cell lysis, the $\mathrm{A}_{3}$ receptor was detected by immunoprecipitation with a specific antibody and Protein A-sepharose, followed by protein resolution on $11 \%$ SDS polyacrilamide gels as described in Materials and Methods. CHO cells transfected with the human $\mathrm{A}_{3}$ receptor cDNA were used as a positive control. ${ }^{14}$ Under such conditions, the $\mathrm{A}_{3}$ receptor can be detected in both $\mathrm{ADF}$ and $\mathrm{CHO}$ cells as a specific immunoreactive protein band with an apparent molecular weight of $36 \mathrm{kDa}$ (arrow). 

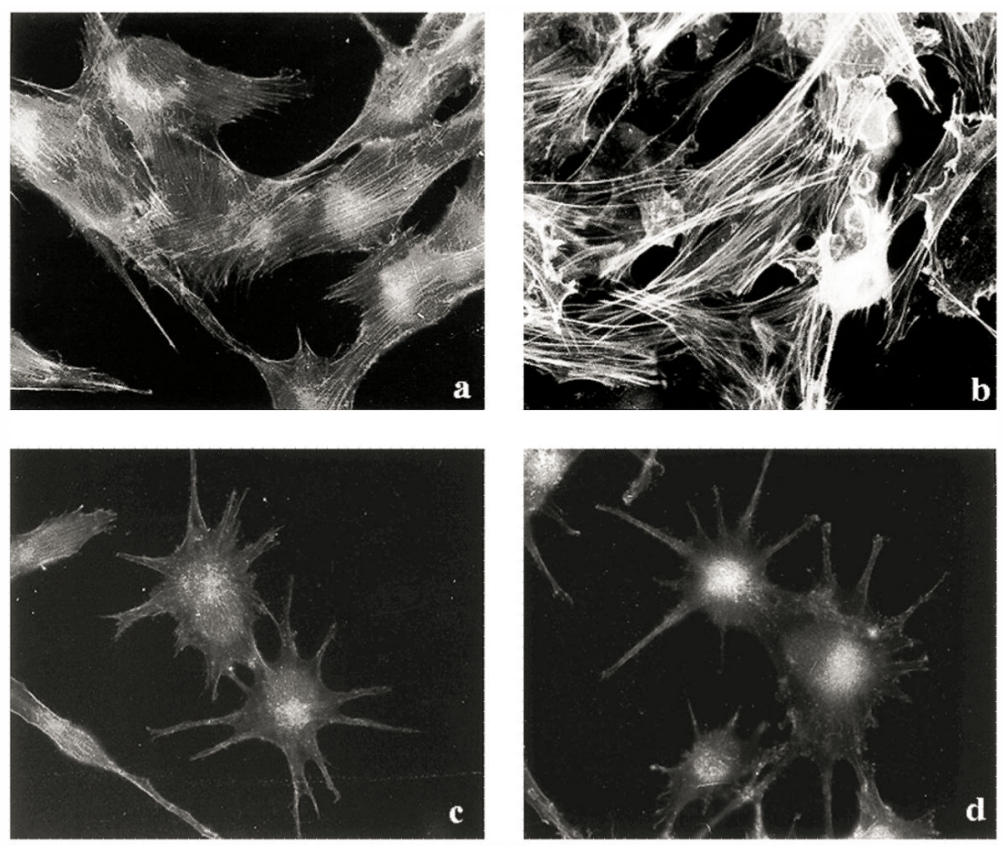

FIGURE 3.

Inhibition of Rho prevented Cl-IB-MECA-induced reinforcement of the actin cytoskeleton. In comparison to control cells (a), exposure of ADF cells to $100 \mathrm{nM}$ Cl-IB-MECA for $48 \mathrm{~h}$ (b) resulted in marked formation of thick actin stress fibers. Exposure of ADF cells to C3B toxin (c) provoked the retraction of the cell body and the break-down of the actin cytoskeleton. Pretreatment of cells with C3B toxin for three hours before exposure to Cl-IB$\operatorname{MECA}(\mathbf{d})$ fully prevented the actin changes induced by the $\mathrm{A}_{3}$ agonist. 


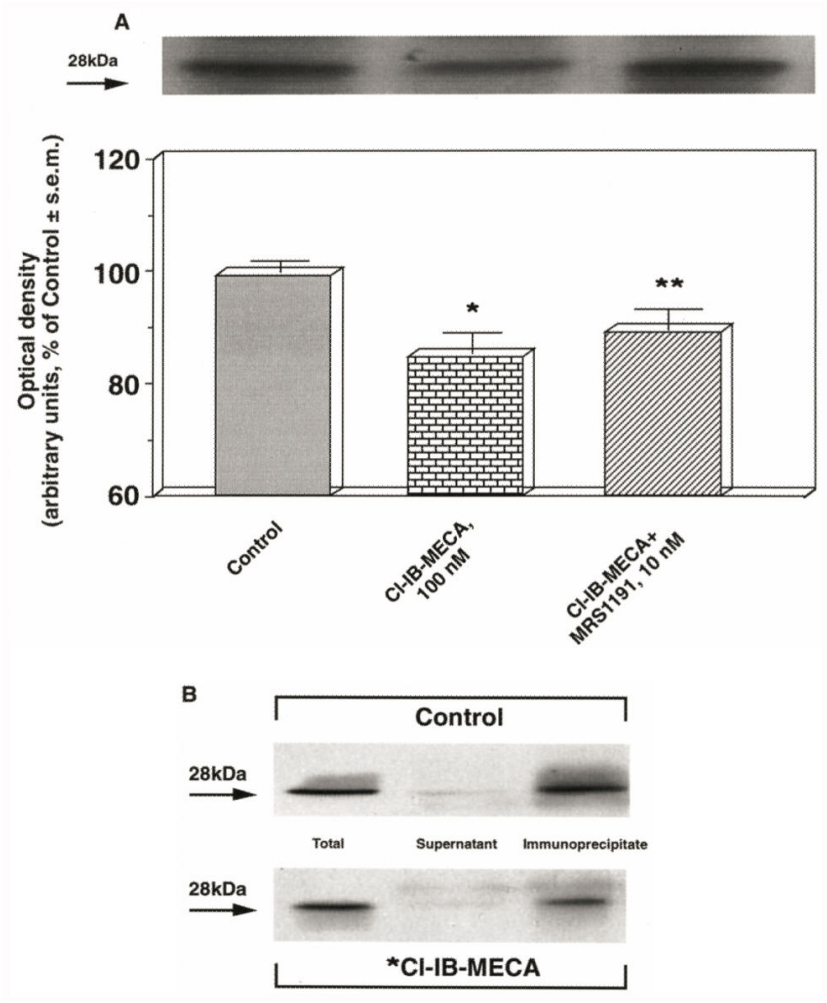

FIGURE 4.

Reduction of Rho-GDI in cultures exposed to Cl-IB-MECA. Cells were exposed to $100 \mathrm{nM}$ Cl-IB-MECA for $48 \mathrm{~h}$ in the absence or presence of MRS1191, as indicated. For the RhoGDI immunoblotting analysis shown in $\mathbf{A}$, cells were lysed, homogenized, proteins separated by SDS-PAGE, and Rho-GDI identified by immunoblot analysis as described in Materials and Methods. For the Rho-GDI immunoprecipitation experiments shown in $\mathbf{B}$, cell homogenates were incubated with the anti-Rho-GDI antibody overnight, and immune complexes separated by centrifugation as described in Materials and Methods. Thus, SDSPAGE and immunoblot analysis were performed on both supernatants and precipitates. ${ }^{*} p<$ 0.05 with respect to control, $* * p<0.05$ with respect to control, and Cl-IB-MECA alone, one way ANOVA (Fisher test). 